\author{
Jerzy Sierociuk \\ Uniwersytet im. Adama Mickiewicza w Ponaniu \\ Instytut Filologii Polskiej \\ ORCID: 0000-0001-9069-6117; e-mail: jasier@amu.edu.pl
}

\title{
Sto lat dialektologii w Poznaniu
}

\begin{abstract}
Abstrakt: W artykule przedstawione są najważniejsze informacje dotyczące historii badań dialektologicznych w Poznaniu. Podano też istotne dane, szkicując kontekst tych działań - działalność naukowa Uniwersytetu Poznańskiego ściśle powiązana jest z Poznańskim Towarzystwem Przyjaciół Nauk. Te dwie instytucje naukowe mają wielkie zasługi w rozwoju studiów polonistycznych, a w tym dialektologii. Przedstawione informacje dotyczą głównie mało znanych osiągnięć zespołu dialektologicznego - między innymi archiwum fonograficznego $\mathrm{z}$ rejestracjami wypowiedzi informatorów urodzonych w drugiej połowie XIX wieku (najstarszy rozmówca pochodzi z roku 1855), co z nagraniami współczesnymi daje w sumie zarejestrowanych około 3700 godzin mowy ludowej - całość tego archiwum dostępna jest w wersji cyfrowej.

Tekst uzupełnia garść informacji o historii dialektologii poznańskiej, zaś kończy szkic współczesnych działań zespołu Pracowni Dialektologicznej UAM - głównie prac leksykograficznych.
\end{abstract}

Słowa kluczowe: historia dialektologii w Poznaniu, polonistyka na UAM, Poznańskie Towarzystwo Przyjaciół Nauk, leksykografia gwar Wielkopolski

Abstract: A centennial of dialectology in Poznań. This article presents the most relevant information on the history of dialectological research in Poznań and its context, the academic achievements of the Poznań University enjoyed in cooperation with the Poznań Society for the Advancement of Arts and Sciences. The two institutions have greatly contributed to the development of Polish studies including dialectology.

The presented information pertains chiefly to the relatively unknown accomplishments of the dialectology team, for example a phonographic archive containing recordings of utterances of informants born in the second half of the $19^{\text {th }}$ century (the oldest interlocutor was born in 1855). Together with contemporary recordings, the collection contains approximately 3,700 hours of rural speech. The entire archive is available in a digital version.

The text is supplemented with information about the history of Poznan dialectology and the contemporary activities of the team of the Dialectology Workshop at the Poznań University, mainly lexicographic works.

Keywords: history of dialectology in Poznań, Polish studies at the AMU, Poznan Society for the Advancement of Arts and Sciences, lexicography of Wielkopolska dialects.

Uniwersytet w Poznaniu powstał - bo mógł - dopiero po uzyskaniu przez Polskę niepodległości. Historia uniwersytecka rozpoczyna się zatem formalnie w roku 1919, 
kiedy to inicjuje działalność Wszechnica Piastowska zmieniająca w roku 1920 nazwę na Uniwersytet Poznański. Od roku 1955 funkcjonuje już jako Uniwersytet im. Adama Mickiewicza w Poznaniu (UAM).

Zabiegi społeczności Poznania o erygowanie tu uniwersytetu mają długą i zawiłą historię. Pierwsze kroki podejmowane były jeszcze w okresie przedrozbiorowym.

w roku 1519 powołana została do życia Akademia Lubrańskiego, która zyskała dumne miano Academia Posnaniensis i uznawana jest dziś za początek poznańskiej tradycji akademickiej. Szkoła ta, jako jedna z pierwszych uczelni Rzeczypospolitej, proponowała nowoczesne, humanistyczne wykształcenie, odbiegające od scholastycznego, średniowiecznego modelu nauczania (Kaniewska 2018, 11).

u progu wieku XVII, w roku 1611 król Zygmunt Waza nadał poznańskiemu kolegium jezuickiemu (powstałemu w roku 1573) przywilej, podnosząc je do rangi akademii. Niestety, edyktu założycielskiego nie podpisał papież, podobno ze względu na protesty Akademii Krakowskiej (Kaniewska 2018, 12).

Nie doczekał się Poznań uniwersytetu w okresie I Rzeczypospolitej. Po rozbiorach kierowane były monity do władz pruskich praktycznie od zakończenia Kongresu Wiedeńskiego. Działania te nie przyniosły jednak pozytywnych rezultatów. Starania o utworzenie uniwersytetu w Poznaniu

rozpoczęły się już u progu powstania Wielkiego Księstwa Poznańskiego petycją złożoną w Berlinie 3 maja 1819 roku, a potem wypływały na posiedzeniach sejmów krajowych w latach 1827 i 1839, przy czym zawsze jedną z podstaw argumentacji wnioskodawców było prawo Polaków do stworzenia katedry języka i literatury polskiej. Władze pruskie natomiast utrącały ten argument, wskazując możliwość stworzenia takiej katedry na istniejących już uniwersytetach w innych miastach pruskich (Wrocławiu, Królewcu, Berlinie) (Maciejewski 2018, 26).

W okresie zaborów uniwersytet w Poznaniu zatem nie powstał. Wprawdzie na mapie miasta mamy wzniesione na początku XX wieku budowle $\mathrm{z}$ przeznaczeniem dla będącej namiastką wyższej szkoły pruskiej - Akademii Królewskiej - z aulą z racji wyjątkowej akustyki wykorzystywaną przez organizatorów koncertów filharmonicznych (z Międzynarodowym Konkursem Skrzypcowym im. Henryka Wieniawskiego włącznie) oraz pomieszczeniami Rektoratu UAM - ale były to działania władz pruskich zmierzających do przekształcenia Poznania w Residenzstadt cesarza. To wtedy - w latach 1902-1918 - po rozbiórce fortyfikacji miejskich powstała tzw. dzielnica zamkowa z budowlami wykorzystywanymi dzisiaj częściowo przez Uniwersytet. Na szczególne podkreślenie zasługuje gmach dawnej Komisji Kolonizacyjnej, będący współczesną siedzibą Wydziału Filologii Polskiej i Klasycznej UAM. Jest to przykład zawiłości historii, ponieważ w locum instytucji powołanej przez władze pruskich zaborców do zwalczania polskości mieszczą się współcześnie zakłady i pracownie polonistyki uznawanej często za najlepszą w kraju. 
Jako młody ośrodek uniwersytecki Poznań borykał się z wypełnieniem składu kadry naukowej. Pośród polonistów największe problemy początkowo były z pozyskaniem językoznawców.

W momencie otwarcia zajęć dydaktycznych katedra języka polskiego na Uniwersytecie Poznańskim nie była (...) obsadzona, a wykłady z tego przedmiotu będą od III semestru prowadzili zastępczo Dobrzycki oraz Lehr i Rudnicki w swych specjalnościach. Dopiero od stycznia 1922 roku objął w tej katedrze wykłady jako „zastępca profesor” przybyły z Krakowa dr Edward Klich. W marcu 1922 roku nastąpiła też wymiana lwowsko-poznańska na katedrze filologii słowiańskiej. Odszedł z Poznania do Lwowa Tadeusz Lehr-Spławiński (po jego wyjeździe przez jeden trymestr wykładał w Poznaniu dialektologię polską Kazimierz Nitsch), a od sierpnia 1922 objął w Poznaniu katedrę filologii słowiańskiej prof. Henryk Ułaszyn ze Lwowa (Maciejewski 2018, 56-57).

Przegrywał też Poznań w pozyskiwaniu kadry z takimi ośrodkami jak Lwów, Warszawa czy Kraków. Przykładem tego jest chociażby Kazimierz Nitsch, który wstępnie przyjąwszy propozycję objęcia katedry języka polskiego Uniwersytetu Poznańskiego, ostatecznie wybrał katedrę filologii słowiańskiej w Krakowie (Maciejewski 2018, 57). Tak więc językoznawstwem od początku swego pobytu w Poznaniu zajmował się Edward Klich ${ }^{1}$, którego „twórczość naukową (...) zainicjował obecny w niej do końca, a okresami dominujący nurt dialektologiczny" (Walczak 2018a, 252).

Z czasem Uniwersytet Poznański wzmacniał swoją pozycję jako ośrodek naukowy; rozwijane były też inne kierunki studiów. To właśnie absolwenci UP przyczynili się do złamania kodu niemieckiej maszyny szyfrującej Enigma. Wysoki poziom akademickiej matematyki oraz doskonała znajomość języka niemieckiego - tradycja ta jeszcze obecnie jest obserwowana wśród najstarszego pokolenia Wielkopolan - umożliwiły sukces stworzonego jeszcze ze studentów matematyki zespołu dekryptażu. Obecnie uniwersytet udostępnia Centrum Szyfrów Enigma - znane bardziej jako Muzeum Enigmy - dokumentujące olbrzymi sukces swoich absolwentów będący istotnym wkładem w szybsze zakończenie II wojny światowej.

$\mathrm{Z}$ biegiem lat wśród kadry naukowej zaczęli pojawiać się już absolwenci UP. Jednym z nich był doc. Adam Tomaszewski - Wielkopolanin, który położył podwaliny pod dynamicznie rozwijającą się na UP dialektologię (Kobus 2017; Lewaszkiewicz 2018). Niemniej nadal odczuwany był brak odpowiedniej kadry, toteż na porządku dziennym były „wykłady gościnne”. Pobyt - wprawdzie krótki - K. Nitscha miał niewątpliwy wpływ na przyjmowane w Poznaniu założenia metodologiczne badań gwaroznawczych; to właśnie tutaj został dostrzeżony - i doceniony - przez krakowskiego uczonego młody A. Tomaszewski. Tymi relacjami należy w przyszłości tłumaczyć wpływ metodologiczny ,szkoły krakowskiej” w badaniach przedstawicieli poznańskiej dialektologii, którą $\mathrm{w}$ drugiej połowie $\mathrm{XX}$ wieku praktycznie sterował prof. Zenon

${ }^{1}$ Ciekawym przyczynkiem do historii poznańskiej polonistyki jest pochodząca z księgozbioru E. Klicha praca J.F. Karskiego, na której obok autografu właściciela jest ślad czasu okupacji - ten bibliofilski okaz od pewnego czasu jest w moim posiadaniu. Jewfimij (Jefim) Fiodorowicz Karski (1860-1931), białoruski językoznawca i etnograf. W latach 1893-1915 przebywał w Warszawie, gdzie dwa razy wybierany był (w latach 1905 i 1908) rektorem Cesarskiego Uniwersytetu Warszawskiego (Императорский Вариавский Университет). 
Sobierajski - uczeń A. Tomaszewskiego. Zależność metodologiczna od K. Nitscha na płaszczyźnie dialektologicznej jest bezsporna; zresztą nie tylko jego.

Dopiero od czasów Rozwadowskiego, Nitscha i Łosia można mówić o w pełni zorganizowanej, systematycznej działalności naukowej i pedagogicznej w dziedzinie językoznawstwa polskiego, słowiańskiego i indoeuropejskiego w Polsce na poziomie światowym i jest to zarazem szczęśliwy zbieg okoliczności, że tych trzech uczonych mogło przez dłuższy czas współdziałać w jednym miejscu, tworząc językoznawczy ośrodek naukowy (tzw. krakowską szkołę językoznawczą). Na owoce ich pracy nie trzeba było długo czekać. Większość językoznawców polskich następnych pokoleń była przeważnie albo ich bezpośrednimi uczniami, albo w jakiś sposób od nich zależna, choć kształcona w innych ośrodkach [podkr. - JS] (Piwowarczyk 2020, 135).

Dialektologię w okresie międzywojennym na Uniwersytecie Poznańskim rozwijał E. Klich, jednak to kto inny bardziej jest kojarzony z rozwojem tej dyscypliny w Poznaniu. To Wielkopolanin - urodzony w Łopiennie w pow. wągrowieckim - A. Tomaszewski. Obu jednak nie było dane kontynuować swoich badań po zakończeniu wojny; obaj jej nie przeżyli - E. Klich jako pierwszy z polskich profesorów był rozstrzelany niedługo po wkroczeniu Niemców do Poznania (Walczak 2018a); A. Tomaszewski zmarł w ostatnich dniach wojny w drodze do domu po wyzwoleniu z obozu koncentracyjnego (Lewaszkiewicz 2018).

Mimo represji okupanta poznańskie środowisko naukowe zaangażowane było w nauczanie na poziomie wyższym; działał - wprawdzie poza Poznaniem - Uniwersytet Ziem Zachodnich (Wikarjak 1972) dowodzący troski Wielkopolan o swój uniwersytet niezależnie od zewnętrznych warunków.

Po wojnie Uniwersytet Poznański rozwijał się dynamicznie, tu także szczególne miejsce zajmowała dialektologia. W naszym kontekście ważne będą następujące informacje: noszący od 1955 roku oficjalną nazwę Uniwersytet im. Adama Mickiewicza w Poznaniu ostatnimi laty zaliczany jest do wielkiej trójki uniwersytetów polskich; poznańska polonistyka powszechnie uznawana jest za najlepszą w kraju; dialektologia poznańska jako jedna z nielicznych ma wyodrębnioną placówkę organizacyjną - od 1974 roku był to samodzielny Zakład Dialektologii Polskiej przekształcony z kolei w Pracownię Dialektologiczną (więcej o tym dalej).

Trudno mówić o poznańskim ośrodku naukowym bez przywołania chociaż pokrótce zasług poznańskiego towarzystwa naukowego. Wobec braku jakichkolwiek nadziei na erygowanie uniwersytetu społeczność Wielkopolski powołała Towarzystwo Przyjaciół Nauk Poznańskie, które swoją działalność rozpoczęło 13 lutego 1857 roku. Założyciele Towarzystwa stawiali sobie za cel ochronę i rozwój zagrożonej kultury narodowej. Korporacja ta niejako zastępowała więc uniwersytet, będąc animatorem życia naukowego w tej części zaboru pruskiego. Zorganizowane wydziały prowadziły regularne badania naukowe; biblioteka gromadziła wiele bezcennych dla kultury polskiej zabytków naszego piśmiennictwa (i nie tylko). Podstawowy trzon zasobów bibliotecznych stanowią bezcenne księgozbiory darowane Towarzystwu przez jego członków zwłaszcza z początkowego okresu działalności. Współcześnie zasoby powiększane są przede wszystkim poprzez wymianę międzybiblioteczną (głównie międzynarodową) 
oraz profilowane zakupy własne. Długoletnia tradycja przesądza, że mimo ubytków spowodowanych działaniami dwu wojen światowych biblioteka PTPN jest doskonałym miejscem pracy dla osób zainteresowanych szeroko pojmowaną humanistyką.

PTPN skupiało nie tylko osoby zaangażowane w ochronę polskości na terenie zaboru pruskiego. To po części Towarzystwu należy przypisać osiągnięcia przeciwdziałające germanizacji; wyraźnie świadczą o tym liczby:

Wg danych z 1846 roku w Wielkim Księstwie Poznańskim mieszkało 1342 tys. osób, z czego Polaków 841 tys. (63\%), Niemców 420 tys. (31\%) i Żydów 81 tys. (6\%).

Natomiast w 1905 roku kształtowało się to następująco: 1990 tys. osób, z czego Polaków 1220 tys. (61\%), Niemców 770 tys. (39\%), do których zaliczono wszystkich Żydów.

Wynika z tego, iż prawie 100-letnia germanizacja nie przyniosła żadnych widocznych efektów (Jędraszewski, Szczepaniak 2010, 9).

Istotny obraz wyłania się też z materiałów niemieckich dotyczących relacji narodowościowych w niektórych rejonach Wielkopolski. Wedle badań Stanisława Malepszaka dokumenty niemieckie jednoznacznie dowodzą, że w roku 1918 Bukówiec Górny i wiele wsi okolicznych w powiecie leszczyńskim - był miejscowością zamieszkaną wyłącznie przez Polaków, co nie znaczy, że w niektórych okolicach nie było inaczej (Malepszak 2007, 207). Nie dziwi zatem też specyficzny rozkład germanizmów w gwarach tego rejonu; obszary intensywnej kolonizacji pruskiej nie przynoszą znacznej ich koncentracji w lokalnych gwarach (Gliszczyńska 2007, 280).

Jest więc oczywiste, że w takiej sytuacji Poznańskie Towarzystwo Przyjaciół Nauk zaangażowało się w tworzenie nowego uniwersytetu. $\mathrm{Z}$ jego grona wywodziło się gremium pierwszej kadry naukowej, to członkowie PTPN przewodzili nowej uczelni.

Duże zasługi ma Wydawnictwo PTPN w promowaniu problematyki dialektologicznej, dorobku dialektologów poznańskich. W 1960 roku zostało reaktywowane samodzielne wydawanie czasopisma poświęconego kwestiom języka i kultury zachodnich Słowian - „Slavia Occidentalis”, na którego łamach ukazało się wiele artykułów poświęconych analizie różnych aspektów gwar wielkopolskich - i nie tylko tych. To w tym też wydawnictwie udostępniono obszerny Kwestionariusz do Atlasu języka i kultury ludowej Wielkopolski (Sobierajski 1972). Z PTPN od początku związane są „Gwary Dziś” - wstępnie jako seria publikująca materiały ze współorganizowanego z Instytutem Filologii Polskiej UAM cyklu międzynarodowych konferencji pod tytułem „Gwary dziś”; od 2015 roku jest to już internetowy rocznik poświęcony dialektologii słowiańskiej (http://gwary.ptpn.poznan.pl/pl/index-pl/). Warto dodać, że to właśnie wzrost prestiżu międzynarodowego przejawiający się między innymi coraz większą liczbą zagranicznych uczestników konferencji pozwolił właśnie w środowisku poznańskim przygotować wniosek na XIV Międzynarodowy Kongres Slawistów w Ochrydzie (2008) o afiliowanie przy MKS Komisji Dialektologicznej.

Dialektologia na Uniwersytecie Poznańskim rozwijała się niejako dwukierunkowo - jej podstawowy nurt wywodzi się z działań podejmowanych przez ówczesnego docenta Ludwika Zabrockiego, który „Już w 1946 r. (w sierpniu) (...) przystąpił do organizowania stosownej placówki badawczej, nazywanej potocznie «Archiwum Fonograficzne». W rozwojowej fazie istniała ona w ramach Instytutu Zachodniosłowiańskiego” 
(Nowak 2001, 201). Oficjalnie placówka ta pierwotnie nosiła nazwę Archiwum Fonograficzne Instytutu Zachodniosłowiańskiego Uniwersytetu Poznańskiego. Kolejne lata przyniosły zmiany organizacyjne, był to więc Instytut Fonograficzny Uniwersytetu Poznańskiego (od 1951), Zakład Fonograficzny przy Katedrze Języka Polskiego UP (od 1952), Pracownia Archiwizacji Gwar przy Katedrze Językoznawstwa Ogólnego UAM (w latach 1960-1969), Zakład Dialektologii Polskiej (Nowak 2001, 202-203) związany z Instytutem Filologii Polskiej UAM (w latach 1974-2009) i wreszcie Pracownia Dialektologiczna przy IFP UAM (od 2009). Taki jest „,rodowód” współczesnych badań dialektologicznych na UAM w Poznaniu. Ta ,pozapolonistyczna” tradycja dialektologii zachowana jest do dzisiaj w lokalizacji gabinetów - przed przeprowadzką do gmachu przy ul. Fredry $10 \mathrm{w}$ starej siedzibie polonistyki w Collegium Novum dialektologia mieściła się na ostatnim piętrze razem z germanistami, podczas gdy pomieszczenia polonistyki zlokalizowane zostały niżej, na piętrach II i III. Dzisiaj też nasze gabinety ulokowane są na poddaszu (IV piętro), co ma też dobre strony, ponieważ niższe pomieszczenia i „połamane” przestrzenie nie zakłócają akustycznych warunków odsłuchów nagrań wcześniej poczynionych w czasie badań terenowych.

Dialektologia poznańska to też wyraźny wkład środowiska związanego strukturą z polonistyką. W latach powojennych istotny udział w rozwoju polonistycznego środowiska lingwistycznego - także dialektologii - wniósł między innymi (pełniąc nawet funkcję dziekańską) prof. Stanisław Urbańczyk (w Poznaniu w latach 1947-1956), największy zaś wkład w pomnażanie wiedzy o złożoności (głównie systemowej) gwar wielkopolskich wśród „,polonistów” mieli: prof. Monika Gruchmanowa i prof. Zygmunt Zagórski. To spod ich piór wyszły na przykład monograficzne ujęcia gwar Wielkopolski zachodniej (Gruchmanowa 1970) i północnej (Zagórski 1967). Zauważalny też był ich wkład w powstanie Atlasu języka i kultury ludowej Wielkopolski (o czym dalej).

Więcej informacji o rozwoju polonistycznego językoznawstwa (w tym dialektologii) na UAM przedstawia Z. Zagórski (Zagórski 2011), wykaz profesorów mających szczególny wpływ na rozwój poznańskiej kadry polonistycznej przybliża z kolei B. Walczak (Walczak 2018b, 303-306).

Badanie gwar wielkopolskich jest ważne nie tylko w kontekście ogólnej charakterystyki gwar polskich i słowiańskich. Może nawet ważniejsze jest ich dokumentowanie z racji roli tychże w kształtowaniu się języka (i kultury) narodowego. Ponadto peryferyjne położenie Wielkopolski na językowej mapie Polski (i Słowiańszczyzny) przesądza o tym, że mamy tu zachowanych wiele elementów archaicznych - tzw. archaizmów peryferycznych - dających wgląd w dawne struktury językowe. To tutaj znajdujemy dowody rodzimości niektórych wyrazów (np. murzyn 'ten, kto jest umurzony, tj. ciemny' < gwar. wlkp. murzyć 'czernić' (Sierociuk 2005)), bystry 'jasny' (bystre słońce, bystra sukienka), kromka 'boczna lub końcowa część całości’ (nie tylko kromka chleba 'pierwszy lub ostatni kawałek bochenka chleba' - inaczej niż w języku ogólnym: 'odkrojony kolejny kawałek chleba z jego środkowej (miękkiej) części') kromka kopca, kromka materiału (krawieckie: 'wąski - po bokach - pasek materiału przy rozwijaniu go z beli') itp. Wiele poświadczeń pojawia się dopiero podczas intensywnych eksploracji terenowych. W większości wypadków są to wyrazy pozbawione swojej dokumentacji leksykograficznej, tym samym często nie są obecne w lingwistycznej świadomości badawczej. 
Historia przesądziła, że gwary wielkopolskie we wczesnym okresie dokumentacji języka polskich mieszkańców wsi nie cieszyły się szczególnym zainteresowaniem (Sierociuk 2013), stąd też braki dokumentacyjne widoczne chociażby w najnowszym, ogólnopolskim Słowniku gwar polskich (SGP). Analiza zawartych tam materiałów jednoznacznie potwierdza stan doskonale znany w środowisku dialektologicznym, oczekującym rychłego wypełnienia tych luk (Karaś 2011, 58, 293). Wypiski z dzieła Oskara Kolberga (Kolberg 1875-1882) oraz z pochodzących z lat 1930-1932 notatek A. Tomaszewskiego (Sierociuk 2019b) nie dają podstaw do szkicowania charakterystyki tym bardziej obserwowania dynamiki zmian - gwar wielkopolskich.

Okres powojenny w historii poznańskiej dialektologii to intensywne działania na polu dokumentowania zasobów gwar wielkopolskich. Od początku działalności zespołu archiwizującego mowę mieszkańców wsi powiększano dokumentację terenową, najpierw kilkuminutowe rejestracje na płytach decelitowych, potem na nośnikach magnetofonowych, wreszcie rejestracje cyfrowe. W roku 2001 ówczesny kierownik Zakładu Dialektologii Polskiej - prof. Henryk Nowak - przekazując mi niejako odpowiedzialność za dalszy rozwój poznańskiej dialektologii, pisał:

Zakład Dialektologii Polskiej dysponuje (...) fonograficznymi tekstami gwarowymi z 520 miejscowości z różnych regionów Polski. (...) Te foniczne archiwalia dialektologiczne, wyrażone w jednostkach czasu, dają łącznie około 520 godzin nagranej mowy ludowej (Nowak 2001, 205).

Wspomniane rejestracje są najcenniejsze z racji czasu ich pozyskiwania jak i charakterystyki samych respondentów. Przywołajmy kilka danych:

Najstarsze nagranie przeprowadzono już 8.08.1945 roku; rozmówcą Tadeusza Wronkowskiego był ur. w 1918 roku mieszkaniec Poznania. Całość dokumentacji obejmuje 44'37”. Do roku 1947 przeprowadzono jeszcze kilka nagrań (od 19'56" do 40’00"). Później - już bardzo systematycznie - gwary różnych regionów (głównie Złotowskie, ale i repatriantów z Rumunii wraz z mieszkańcami miast czeskich - Brno - i albańskich m.in. Tirana) utrwalał twórca poznańskiego archiwum, profesor L. Zabrocki. Od roku 1949 pozyskiwaniem tekstów gwarowych kieruje ówczesny doktor Z. Sobierajski. Ze względu na ograniczoną pojemność płyt wypowiedzi niektórych rozmówców trwały początkowo nie dłużej niż 4-5 minut. Oczywiście, tych płyt w konkretnej miejscowości nagrywano kilka. W miarę wyposażania zespołu poznańskiego w stosowny sprzęt wzrasta długość dokonywanych rejestracji (ciągle jednak na płytach). Współcześnie wszystkie materiały - te najstarsze i najnowsze - są już zdigitalizowane; w nowym katalogu każda pozycja uwzględnia wiele parametrów, które zostały swego czasu zasygnalizowane w przyjmowanych przez zespół założeniach metodologicznych (Sierociuk 2003).

Najstarszy informator, którego wypowiedź przechowywana jest w archiwum Pracowni Dialektologicznej UAM, urodził się w roku 1855 (sic!); był nim mieszkaniec Bukowskiej Woli koło Miechowa w Krakowskiem. Z. Sobierajski utrwalił w sumie 52’40" jego wypowiedzi. Dla uświadomienia wartości naszych materiałów podam jeszcze kilka kolejnych wypisów katalogowych (nagrań głównie z terenu Wielkopolski):

- inf. ur. w 1860 roku; Nowa Wieś Królewska k/Wrześni (71'10”),

- inf. ur. w 1862 roku; Dąbrowa k/Wielunia (35'46”),

- inf. ur. w 1864 roku; Mańkowice k/Nysy (04’38”),

- inf. ur. w 1866 roku; Kawęczyn k/Szczytna (09'08”), 


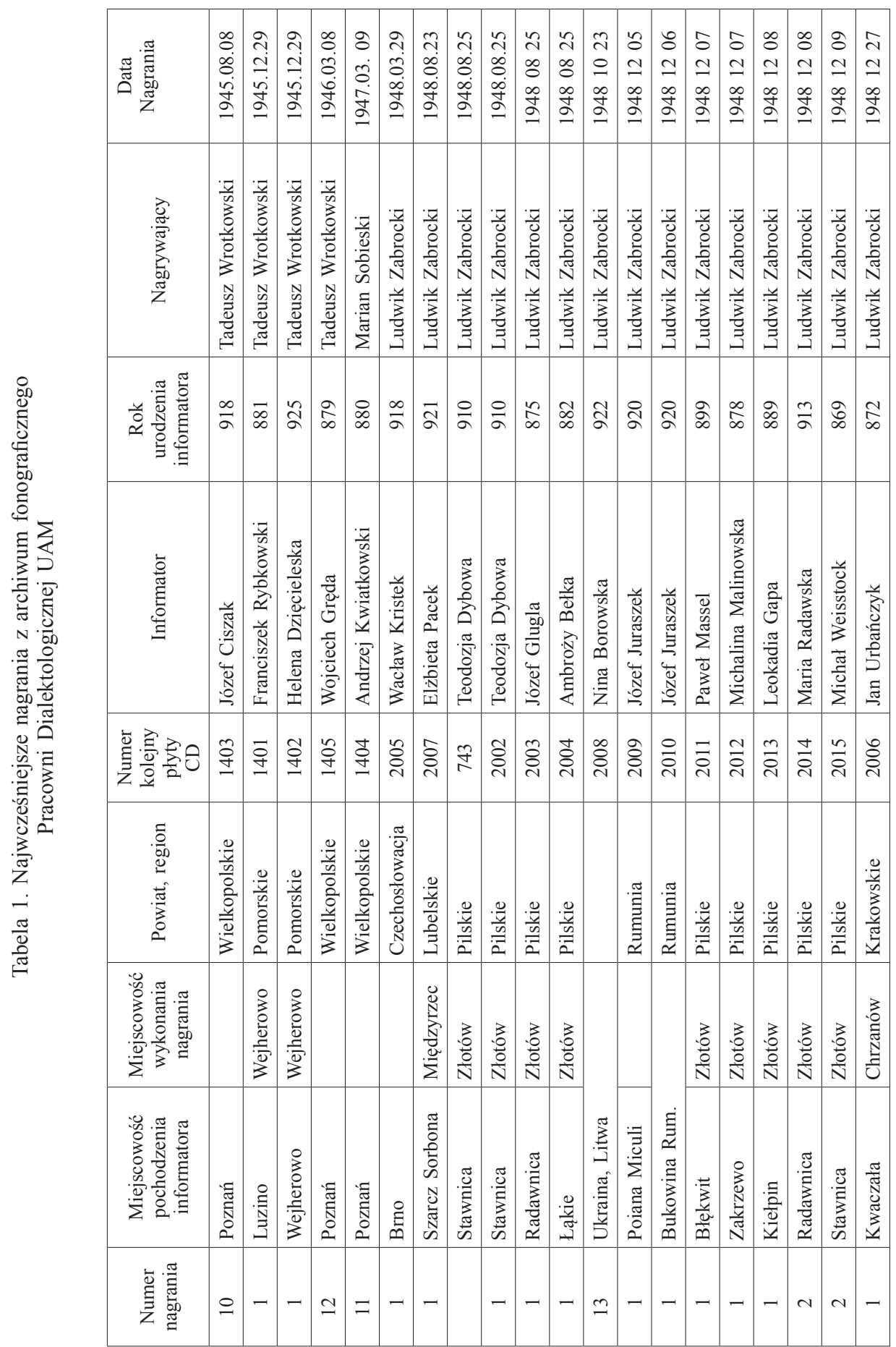




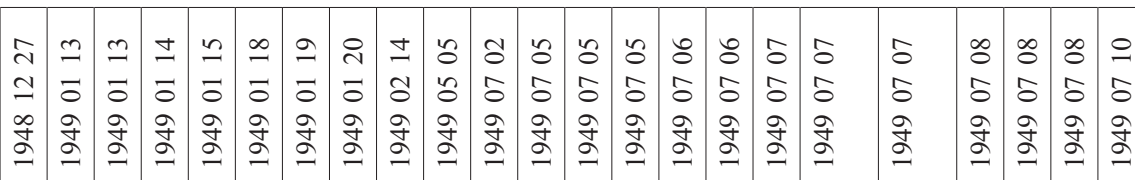

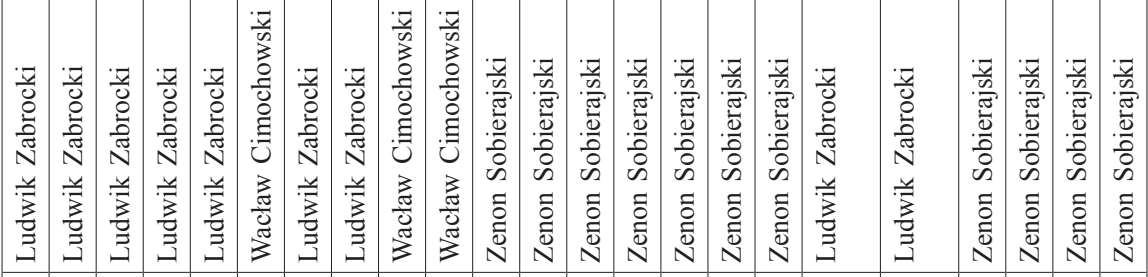

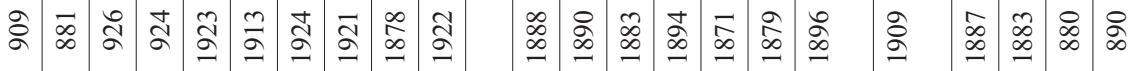

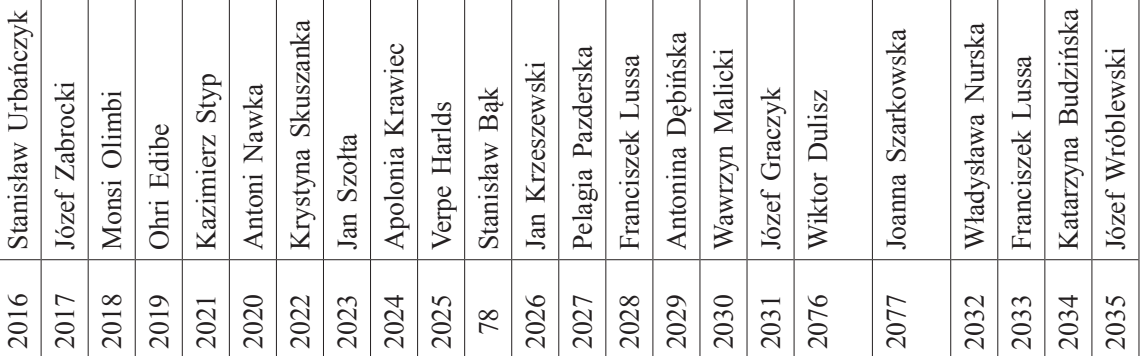

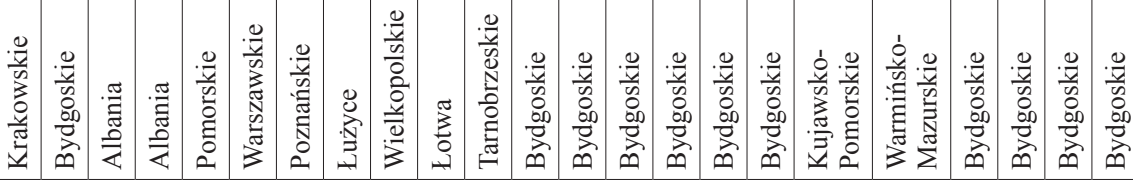

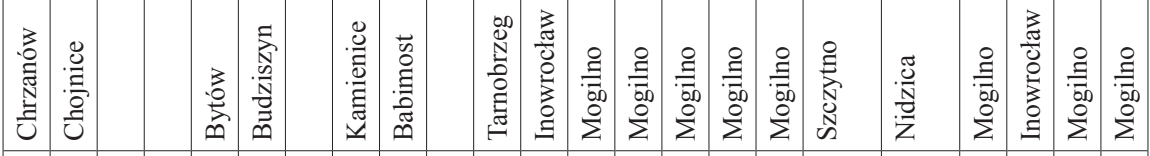

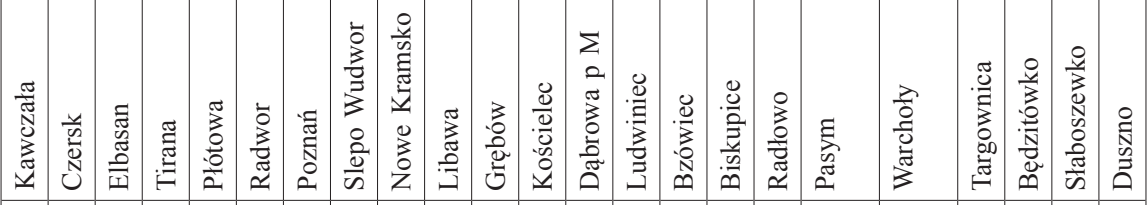

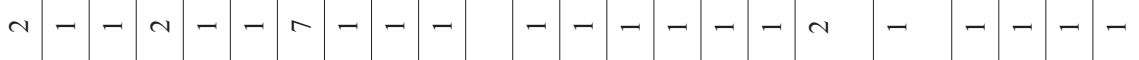


- inf. ur. w 1866 roku; Drawsko k/Czarnkowa (58'36"),

- inf. ur. w 1866 roku; Wyszyny k/Chodzieży (53'25'),

- inf. ur. w 1866 roku; Morzewo k/Chodzieży (29'47'),

- inf. ur. w 1867 roku; Wijewo k/Leszna (63'26”),

- inf. ur. w 1868 roku; Królikowo k/Żnina (30’43”).

Dla porządku przywołajmy też wyciągi z najwcześniejszych protokołów. Poszczególne kolumny zawierają następujące informacje z współcześnie opracowanego katalogu: kolejny numer nagrania-płyty (CD w aktualnym archiwum) z danej miejscowości; miejscowość nagrania; powiat (wedle dawnego podziału administracyjnego); region (praktycznie jest to województwo); numer kolejny płyty CD; informator ${ }^{2}$; rok urodzenia informatora; nagrywający; data nagrania.

Nie tylko dla badacza zainteresowanego dynamiką zmian językowych zachodzących w środowisku wsi istotne jest określenie wieku rozmówców. Wcześniej przywołałem charakterystyki kilku najstarszych respondentów wielkopolskich - warto jednak poświęcić nieco miejsca na przedstawienie pochodzących z różnych regionów Polski najbardziej wiekowych informatorów (w porównaniu $\mathrm{z}$ zestawieniem przywołanym wyżej pominięte zostały dwie ostatnie kolumny).

Tabela 2. Najstarsi informatorzy, których utrwalone wypowiedzi znajdują się w archiwum fonograficznym Pracowni Dialektologicznej UAM

\begin{tabular}{|c|l|l|l|c|l|c|}
\hline \multirow{2}{*}{$\begin{array}{c}\text { Miejscowość } \\
\text { pochodzenia } \\
\text { informatora }\end{array}$} & $\begin{array}{c}\text { Miejscowość } \\
\text { wykonania } \\
\text { nagrania }\end{array}$ & Powiat, region & $\begin{array}{c}\text { Numer } \\
\text { kolejny } \\
\text { płyty } \\
\text { CD }\end{array}$ & Informator & $\begin{array}{c}\text { Rok } \\
\text { urodzenia } \\
\text { informatora }\end{array}$ \\
\cline { 2 - 7 } & Bukowska Wola & Miechów & Krakowskie & 307 & Andrzej Michalski & 1855 \\
\hline 1 & $\begin{array}{l}\text { Nowa Wieś } \\
\text { Królewska }\end{array}$ & Września & Wielkopolskie & 2204 & Wincenty Szuba & 1860 \\
\hline 1 & Dąbrowa p W & Wieluń & Lódzkie & 2255 & Marianna Kużniak & 1862 \\
\hline 1 & Mańkowice & Nysa & Opolskie & 2043 & Franciszek Hauke & 1864 \\
\hline 1 & Kałęczyn & Szczytno & Warmińsko-Maz. & 2056 & Ludorf Lota & 1866 \\
\hline 16 & Drawsko & Czarnków & Wielkopolskie & 2156 & Małgorzata Smuga & 1866 \\
\hline 3 & Wyszyny & Chodzież & Wielkopolskie & 2168 & Szczepan Wołyński & 1866 \\
\hline 1 & Morzewo & Chodzież & Wielkopolskie & 2229 & Jan Wiorek & 1866 \\
\hline 1 & Wijewo & Leszno & Wielkopolskie & 2155 & Elżbieta Jurowa & 1867 \\
\hline 1 & Królikowo & Żnin & Kujawsko-Pom. & 2162 & Teodor Grabowski & 1868 \\
\hline 1 & Lawki & Mogilno & Bydgoskie & 2038 & Józef Ljankowski & 1869 \\
\hline 1 & Stare Kramsko & Sulechów & Lubuskie & 2134 & Anna Majer & 1869 \\
\hline 1 & Brzoza & Wieluń & Lódzkie & 912 & Marianna Stępień & 1869 \\
\hline
\end{tabular}

${ }^{2}$ Dane osobowe osób nagrywanych i nagrywających upowszechniane były w publikowanych katalogach nagrań (zob. Sobierajski 1957). 


\begin{tabular}{|c|c|c|c|c|c|c|}
\hline 1 & Liwa & Ostróda & Warmińsko-Maz. & 2068 & NN mężczyzna & 1869 \\
\hline 2 & Liwa & Ostróda & Warmińsko-Maz. & 2089 & NN mężczyzna & 1869 \\
\hline 2 & Stawnica & Złotów & Wielkopolskie & 2015 & Michał Weisstock & 1869 \\
\hline 1 & Kiełpiny & Wolsztyn & Wielkopolskie & 2135 & Ludwik Rżanny & 1869 \\
\hline 5 & Wilkowyja & Jarocin & Wielkopolskie & 2175 & Antoni Kubicki & 1869 \\
\hline 4 & Piaski & Gostyń & Wielkopolskie & 2181 & Józefa Jemrychowa & 1869 \\
\hline 1 & Ogonki & Węgorzewo & Warmińsko-Maz. & 2061 & Herman Migge & 1870 \\
\hline 2 & Bańki & $\begin{array}{l}\text { Bielsk } \\
\text { Podlaski }\end{array}$ & Białostockie & 313 & Józef Pęski & 1871 \\
\hline 1 & Biskupice & Mogilno & Bydgoskie & 2030 & Wawrzyn Malicki & 1871 \\
\hline 1 & Łankowiczki & Szubin & Kujawsko-Pom. & 2161 & Jan Najdul & 1871 \\
\hline 1 & Kwaczała & Chrzanów & Krakowskie & 2006 & Jan Urbańczyk & 1872 \\
\hline 6 & Kluki & Shupsk & Pomorskie & 2122 & Henryk Kaitczik & 1872 \\
\hline 1 & Radosty & Olsztyn & Warmińsko-Maz. & 2064 & Anna Greichenberg & 1872 \\
\hline 1 & Wydawy & Rawicz & Wielkopolskie & 358 & Marianna Rajczak & 1872 \\
\hline 2 & Wydawy & Rawicz & Wielkopolskie & 359 & Marianna Rajczak & 1872 \\
\hline 1 & Dobieżyn & Nowy Tomyśl & Wielkopolskie & 2174 & Agn. Łamaszewska & 1872 \\
\hline 1 & Kobylniki & Szamotuły & Wielkopolskie & 2202 & $\begin{array}{l}\text { Matria } \\
\text { Kaczmarkowa }\end{array}$ & 1872 \\
\hline 1 & Topólno & Świecie & Kujawsko-Pom. & 2234 & Ignacy Raniszewski & 1873 \\
\hline 1 & Ciemniki & Świecie & Kujawsko-Pom. & 2238 & $\begin{array}{l}\text { Franciszek } \\
\text { Kopkowski }\end{array}$ & 1873 \\
\hline 1 & Rogojny & Olecko & Warmińsko-Maz. & 2059 & Gustaw Rogowski & 1873 \\
\hline 1 & Obłok & Ostrów Wlkp & Wielkopolskie & 1616 & Antonina Zaręba & 1873 \\
\hline 1 & Parkowo & Oborniki & Wielkopolskie & 2171 & Antoni Tabat & 1873 \\
\hline 1 & Lutogniew & Krotoszyn & Wielkopolskie & 2177 & Franciszka Morgel & 1873 \\
\hline 1 & Kicko-Chełmce & Inowrocław & Bydgoskie & 1307 & Wojciech Skowron & 1874 \\
\hline 2 & Kicko-Chełmce & Inowrocław & Bydgoskie & 1308 & Wojciech Skowron & 1874 \\
\hline 2 & Piaski & Sieradz & Kujawsko-Pom. & 2112 & Antonina Rychlik & 1874 \\
\hline 3 & Piaski & Sieradz & Kujawsko-Pom. & 2113 & Antonina Rychlik & 1874 \\
\hline 1 & Stołuń & Międzyrzecz & Lubuskie & 2130 & Leon Łuka & 1874 \\
\hline 1 & Okalew & Wieluń & Łódzkie & 1628 & Stanisława Głuch & 1874 \\
\hline 1 & Lisia Góra & Słupsk & Pomorskie & 2126 & Herman Szymanke & 1874 \\
\hline 1 & $\begin{array}{l}\text { Osława } \\
\text { Dąbrowa }\end{array}$ & Bytów & Pomorskie & 2246 & Ignacy Kowalewski & 1874 \\
\hline 1 & Bzury & Pisz & Warmińsko-Maz. & 2147 & Jan Trynowała & 1874 \\
\hline 1 & Grodzisko & Strzelce & Dolnośląskie & 2241 & Jan Gomuła & 1875 \\
\hline \multirow[t]{2}{*}{1} & Zboże & Sępólno & Kujawsko-Pom. & 2235 & Jan Mudzik & 1875 \\
\hline & Wróblew & Wieluń & Łódzkie & 914 & $\begin{array}{l}\text { Marcjanna } \\
\text { Szymczewska }\end{array}$ & 1875 \\
\hline
\end{tabular}




\begin{tabular}{|c|l|l|l|l|l|c|}
\hline 1 & Narok & Niemodlin & Opolskie & 2110 & Stanisław Zdzuj & 1875 \\
\hline 1 & $\begin{array}{l}\text { Brzeżno } \\
\text { Gdańskie }\end{array}$ & Gdańsk & Pomorskie & 2072 & Józef Rumczyk & 1875 \\
\hline 1 & Biała Piska & Pisz & Warmińsko-Maz. & 2148 & August Wiśniewski & 1875 \\
\hline 1 & Radawnica & Złotów & Wielkopolskie & 2003 & Józef Glugla & 1875 \\
\hline 1 & Szkaradowo & Rawicz & Wielkopolskie & 2142 & Maria Wormuth & 1875 \\
\hline 1 & Zielona Wieś & Rawicz & Wielkopolskie & 2143 & Karol Bartkowiak & 1875 \\
\hline 1 & Lutomek & Międzychód & Wielkopolskie & 2172 & Andrzej Jenek & 1875 \\
\hline 1 & Bachorzew & Jarocin & Wielkopolskie & 2176 & $\begin{array}{l}\text { Antonina } \\
\text { Wierzchowicka }\end{array}$ & 1875 \\
\hline 4 & Żychlewo & Gostyń & Wielkopolskie & 2223 & Marcin Nawrocki & 1875 \\
\hline
\end{tabular}

Oceniając przydatność fonoteki poznańskiej dla badacza polszczyzny mówionej, należy zwrócić szczególną uwagę na epizod towarzyszący istotnemu osiągnięciu w dorobku polskiego gwaroznawstwa. W zasobach fonograficznych Pracowni Dialektologicznej UAM znajdują się nagrania, których dokonywano równolegle z poczynaniami zespołu kierowanego przez K. Nitscha; dodajmy: nagrania, które doskonale mogą poszerzyć podstawę charakterystyki dialektów polskich drugiej połowy lat 50. ubiegłego wieku. W roku 1953 bowiem „W miarę możliwości starano się W (...) nagraniach uwzględniać takich informatorów, których gwarę wykorzystano już do opracowania kwestionariusza w związku z przygotowywanym przez Polską Akademię Nauk «Małym atlasem gwar polskich» (Sobierajski 1957, 81). W tym czasie były to głównie miejscowości z Wielkopolski wraz z terenami przyległymi: Drawsko, pow. Czarnków³; Wijewo, pow. Leszno; Piaski, pow. Gostyń; Średzkie; Jancewo, pow. Żnin; Walentynowo, pow. Wyrzysk (Krajna i Bory). Później bądź wybierano innych informatorów zamieszkujących miejscowości będące punktami MAGP, bądź nawet udawało się nagrać wypowiedzi tych samych respondentów, od których pozyskiwano materiał do atlasu. Wykaz tych wsi obejmuje kilkanaście pozycji; z podziałem na dialekty są to ${ }^{4}$ :

- ziemia chełmińsko-dobrzyńska: Szczuka, pow. Brodnica;

- Śląsk: Istebna, pow. Cieszyn; Olza, pow. Wodzisław;

- Małopolska: Więciorka, pow. Myślenice; Mokrzesz, pow. Częstochowa; Mrukowa, pow. Jasło; Chomęciska Duże, pow. Zamość; Niebieszczany, pow. Sanok; Chodów, pow. Miechów; Miedzna Murowana, pow. Opoczno; Ujanowice-Konary, pow. Sandomierz; Żelechlinek, pow. Rawa Mazowiecka;

- Mazowsze: Białka, pow. Radzyń Podlaski; Kadzidło, pow. Ostrołęka; Osuchowo Nowe, pow. Ostrów Mazowiecka; Uniszki Zawadzkie, pow. Mława;

- Podlasie: Bańki, pow. Bielsk Podlaski.

O ile mi wiadomo, materiały te nie były poddawane szczegółowym analizom, a przecież mogłyby dostarczyć wiele informacji ułatwiających opracowanie szerszej charakterystyki lokalnych gwar. Nie były wykorzystywane między innymi jako cenne

\footnotetext{
3 Podział na powiaty zgodny ze stanem ówczesnym.

${ }^{4}$ W zestawieniu tym wytłuszczone zostały nazwy miejscowości, gdzie nagrywano respondenta będącego wcześniej informatorem przy wypełnianiu kwestionariusza dla MAGP.
} 
źródło przy badaniach składniowych. Poza wszelką dyskusją pozostają wartością samą w sobie, także przy opisie zjawisk właściwych innym poziomom analizy lingwistycznej.

Aktualnie w zasobach fonograficznych Pracowni Dialektologicznej UAM znajduje się ponad 3700 godzin rejestracji rozmów prowadzonych z informatorami zamieszkującymi różne rejony Polski; mamy także nagrania czynione wśród Polonii w Kazachstanie i na Ukrainie. Wykaz godzin nagrań (wszystkie rejestracje są już dostępne w wersji cyfrowej) jest pochodną założenia metodologicznego, że każda - nawet najkrótsza - rozmowa jest rejestrowana; $\mathrm{z}$ drugiej strony pojawia się nieraz pytanie - często formułowane przez studentów - ,po co to robimy, skoro nie zdołamy tego samodzielnie opracować?”. Przyświeca nam jednak założenie, że w sytuacji dynamicznego rozwoju (i przekształcenia) polszczyzny musimy uzupełniać podstawę badawczą dla przyszłych pokoleń; mówiąc ogólnie: żeby za około 50 lat, ktoś, kto będzie chciał poddać analizie przebieg procesów rozwojowych polszczyzny, miał materiał do niezbędnych analiz.

Koncentracja uwagi badawczej na gwarze jednego środowiska wiejskiego pozwala już dzisiaj z pewną doza prawdopodobieństwa szkicować charakterystykę języka tej społeczności w określonych przedziałach czasowych. Wieloletnia obserwacja mowy mieszkańców Bukówca Górnego (pow. Leszno) zaowocowała nie tylko powiększeniem archiwum o ponad 200 godzin rozmów, w których w różnym stopniu udział wzięło około 70 osób. Jest to rzadko spotykana sytuacja, kiedy daną gwarę dokumentują tak obszerne wypowiedzi tylu jej użytkowników. Uwzględnianie w tych eksploracjach czynnika pokoleniowego pozwoliło przykładowo stwierdzić wypadnięcie z systemu miejscowej gwary między innymi specyficznych form $-\mathrm{z}$ reduplikacją $-n-\mathrm{w}$ przymiotnikach odmateriałowych (głównie) typu glinianny, drewnianny, wetnianny. Zjawisko to było możliwe do stwierdzenia dzięki przyjęciu odpowiedniej reprezentacji pokoleniowej w doborze rozmówców.

Zarówno dla potrzeb prowadzonych eksploracji terenowych, jak i konkretnych analiz, bowiem przyjmujemy przynależność pokoleniową wskazywaną rokiem urodzenia informatora. Wynika to z przekonania, że na złożoność zachowań językowych konkretnego osobnika decydujący wpływ ma czas kształtowania się jego kompetencji językowej, czas opanowywania systemu językowego wraz $\mathrm{z}$ odniesieniami kulturowymi. $\mathrm{Z}$ tego też względu - a także dla celów porządkujących - na pierwszym miejscu stawiamy przynależność pokoleniową wyznaczaną rokiem urodzenia. Założenie to bardzo często mogliśmy weryfikować (pozytywnie) w czasie wielokrotnych rozmów z tymi samymi interlokutorami.

Dla potrzeb porządkowych (archiwum) i badawczych przyjęliśmy następujący podział pokoleniowy:

I. Urodzeni przed rokiem 1920. Ta grupa pokoleniowa praktycznie nie jest już reprezentowana wśród współczesnych obiektów badawczych. Jest to pokolenie, które swoje nawyki językowe wyniosło ze środowiska domowego; jest to też pokolenie, na którego język (polski) nie wywierała wpływu szkoła. W praktyce język tego pokolenia jest najlepiej udokumentowany; to język tego pokolenia przedstawiany jest na mapach dostępnych opracowań atlasowych.

II. Urodzeni w latach 1921-1945. Obecnie, mówiąc o pokoleniu najstarszym, praktycznie mamy do czynienia $\mathrm{z}$ przedstawicielami tych właśnie roczników. W środowisku 
wiejskim jest to grupa ludzi wychowana w jednolitych warunkach społeczno-ekonomicznych. Informatorzy w tym czasie urodzeni są głównym źródłem pozyskiwania leksyki związanej z tradycyjnie zorganizowanym życiem wiejskim.

III. Urodzeni w latach 1946-1970. Przynależący do tego pokolenia interlokutorzy wzrastali w odmiennych warunkach społeczno-ekonomicznych charakteryzujących się stopniowym zanikaniem tradycyjnych struktur wiejskich i warunków tradycyjnego wiejskiego życia. Na ich język znaczący wpływ wywiera szkoła i ruchy migracyjne ludności. Nie bez znaczenia są też oddziaływania czynnika zewnętrznego - niespotykany do tej pory wpływ środowiska miejskiego.

IV. Urodzeni w latach 1971-1995. Jest to pokolenie najbardziej zróżnicowane pod względem warunków kształtowania się jego sprawności językowej. Przeobrażenia społeczne i ekonomiczne odciskają tu najwyraźniej swoje piętno. Zachodzące na wsi zmiany pod wpływem czynników zewnętrznych (m.in. upowszechniona elektryfikacja, sieć wodociągowa, inne środki produkcji rolnej itp.) powodują, że głównie na poziomie leksykalnym mamy do czynienia z nową rzeczywistością.

V. Uurodzeni w roku 1996 i później. Jest to pokolenie wzrastające w warunkach pogłębiających się przeobrażeń wzrostu pokolenia poprzedniego. Obserwacja procesu kształtowania się języka przedstawicieli tego pokolenia daje podstawy do wnioskowania o tempie przemian językowych zachodzących w przyszłości w tym środowisku (Sierociuk 2003, 134).

Zdecydowanie się na wyżej zarysowany podział pokoleniowy umożliwia między innymi wieloletnie prowadzenie badań z tymi samymi informatorami. Jednocześnie pozwala wykorzystywać w badaniach nad procesami ewolucyjnymi istotne dwa parametry: rok zapisu konkretnej formy oraz rok urodzenia informatora, przez którego została ona podana. W wielu wypadkach umożliwia to właściwą interpretację danych pozyskiwanych wiele lat później w punktach swego czasu eksplorowanych dla potrzeb konkretnych badań. Przykładem tego mogą być konfrontacje współczesnych notowań z materiałami do AJKLW, które to pozyskiwane były w pierwszej dekadzie lat 70 . ubiegłego wieku (Sobierajski 1972).

Atlas języka i kultury ludowej Wielkopolski (AJKLW) jest wspólnym dziełem dwu zespołów badawczych UAM - dialektologów i etnografów. Kwestionariusz do tego dzieła powstał wspólnym wysiłkiem całego środowiska poznańskich dialektologów i etnografów. Poza głównym redaktorem - Z. Sobierajskim - należy odnotować wyraźny wkład dialektologiczny M. Gruchmanowej, H. Nowaka i Z. Zagórskiego (Sobierajski 1972).

AJKLW to 889 map pogrupowanych tematycznie w 11 tomach. Mamy więc tu bardzo dokładny obraz językowo-kulturowego zróżnicowania mowy mieszkańców wielkopolskich wsi. Ujęcia kartograficzne dokumentują stan gwary, który współcześnie należy już zasadniczo do przeszłości. Odnotujmy, że większość map lingwistycznych jest autorstwa H. Nowaka, którego praktycznie należy uznać za głównego wykonawcę tej partii Atlasu... (Sierociuk 2018).

Mimo że mapy dialektalne przynoszą wiele informacji pozwalających określać specyfikę badanych gwar, to jednak nie do końca objaśniają na przykład znaczenie mapowanych wyrazów. Prezentacji semantyki (znaczenia i kontekstowego użycia) wyrazów gwarowych służy jednak słownik. 
Pierwsze dziesięciolecie XXI wieku to praktycznie całkowita wymiana kadrowa a także nakreślenie nowych planów badawczych. W roku 2002 na emeryturę przeszedł kierownik Zakładu Dialektologii Polskiej UAM prof. Henryk Nowak, który ostanie lata życia (zmarł w roku 2010) poświęcił głównie kontynuacji pracy nad Słownikiem gwary chazackiej. W zamierzeniach autora miał to być słownik obszerny z bogatą dokumentacją leksykograficzną podawaną bardzo dokładnej transkrypcji fonetycznej; praca nad nim nie wyszła jednak poza wstępną fazę (Sierociuk 2018). Do roku 2007 - roku śmierci - działalnością głównie organizacyjną (związaną $\mathrm{z}$ wydawaniem AJKLW) zajmował się prof. Z. Sobierajski (Walczak 2018c, Sierociuk 2020).

Po odejściu Profesorów należało skupić się na odbudowaniu zasobów kadrowych oraz naszkicować perspektywy badawcze nowego, młodego zespołu. O ile pod względem osobowym zespół badawczy pozostał w niezmienionym stanie - trzy osoby (prof. dr hab. Jerzy Sierociuk - kierownik, oraz dwoje studentów zatrudnionych tylko na połowie etatu technicznego), to jednak osiągnięto wzmocnienie naukowe. Awansem naukowym - właśnie od studenta do samodzielnego pracownika nauki - mogą pochwalić się: dr hab. Justyna Kobus i dr hab. Blażej Osowski. To Oni - rodowici Wielkopolanie - w najbliższych latach będą dbać o pozycję dialektologii poznańskiej. Szansą na przyszłość są też realizowane w Pracowni Dialektologicznej kolejne doktoraty.

W środowisku dialektologicznym - nie tylko wielkopolskim - szczególnie dotkliwie od wielu lat odczuwany jest brak odpowiedniej dokumentacji leksykograficznej wielkopolskich gwar. Analiza materiału zawartego w SGP jednoznacznie dowodzi, że dialekt ten ma tu najsłabszą reprezentację. Na potrzebę wypełnienia tej luki coraz wyraźniej zwracana jest uwaga nie tylko środowiska leksykograficznego, a przecież to gwary wielkopolskie mają znaczący wkład w ostateczne kształtowanie się polskiego języka literackiego. Ponadto na tym terenie rodziła się polska państwowość.

Wyraźny obraz bogactwa leksykalnego gwar przynosi wspomniany już krakowski SGP. W ocenach dorobku leksykografii gwarowej znajdujemy wiele niezbyt przychylnych dla poznańskiej dialektologii uwag; dialekt wielkopolski w kartotece SGP bowiem ma bardzo skromną dokumentację (,Wielkopolska jest słabo reprezentowana nie tylko w KarłSPG, ale nawet i we współcześnie opracowywanym SGPPAN" - Karaś 2011, 58). Zważywszy na to, że kartoteka krakowska gromadzi poświadczenia użyć wyrazów gwarowych także tych z XIX wieku, braki dokumentacji wielkopolskiej głównie powojennej - są szczególnie istotne. Fakt ten bowiem w wielu wypadkach zniekształca całościowy opis zjawisk gwarowych przygotowywany na podstawie tejże kartoteki - istnieje w tej sytuacji niebezpieczeństwo interpretacji niektórych zjawisk jako rozwijających się niezależnie (przy braku dokumentacji z pasa wielkopolskiego wobec bogactwa tej z północy i południa Polski).

W kartotece SGP nie ma zbyt wiele wypisków z tekstów (lub opracowań) gwarowych dotyczących Wielkopolski, po prostu takowych Wielkopolska praktycznie jest pozbawiona. W tej sytuacji należy opierać się na przekazywanych materiałach rękopiśmiennych. Tu też nie jest najciekawiej. W wykazie źródeł (SGP 1977) podawane są informacje pozwalające nakreślić reprezentację leksykograficzną poszczególnych rejonów; obejmują one nazwę miejscowości wraz z lokalizacją (uwzględniającą numer w obrębie powiatu), nazwisko eksploratora i rok dokonanego przezeń zapisu oraz 
liczbę dostarczonych kartek. Podobnie postępował zespół redakcyjny, podając na początku informacje o napływających materiałach uzupełniających; od zeszytu 16. (reorganizacja prac redakcyjnych) takich danych jesteśmy pozbawieni. Zestawiając odpowiednio te materiały, uzyskujemy obraz wielce zaskakujący. Tu przytoczę tylko dane dotyczące jednego powiatu - gnieźnieńskiego, jest to istotne w kontekście podejmowanych w Pracowni Dialektologicznej przedsięwzięć leksykograficznych (o tym dalej):

\section{GNIEZNO}

Gniezno (brak numeru w z. 16) - Adam Tomaszewski, 1930-1932, 5 k.

1. Czerniejewo - Adam Tomaszewski, 1930-1932, $10 \mathrm{k}$.

2. Dąbrówka Kościelna - Adam Tomaszewski, 1930-1932, 10 k.

3. Dębłowo - Adam Tomaszewski, 1930-1932, $10 \mathrm{k}$.

4. Dębnica - Adam Tomaszewski, 1930-1932, $10 \mathrm{k}$.

5. Dziekanowice - Adam Tomaszewski, 1930-1932, $10 \mathrm{k}$.

6. Imiołki - Adam Tomaszewski, 1930-1932, $10 \mathrm{k}$.

7. Kamieniec - Adam Tomaszewski, 1930-1932, $10 \mathrm{k}$.

8. Kiszkowo - Adam Tomaszewski, 1930-1932, 10 k.

9. Mielżyn - Adam Tomaszewski, 1930-1932, $10 \mathrm{k}$.

10. Niechanowo - Kazimierz Nitsch, 1904-1939, 50 k.

Adam Tomaszewski, 1930-1932, $10 \mathrm{k}$.

11. Ostrowite Prymasowskie - Adam Tomaszewski, 1930-1932, 10 k.

12. Powidz - Adam Tomaszewski, 1930-1932, 10 k.

13. Skorzęcin - Adam Tomaszewski, 1930-1932, $10 \mathrm{k}$.

14. Strzyżewo - Adam Tomaszewski, 1930-1932, $10 \mathrm{k}$.

15. Ujazd - Adam Tomaszewski, 1930-1932, $10 \mathrm{k}$.

16. Węgorzewo - Adam Tomaszewski, 1930-1932, $10 \mathrm{k}$.

17. Wierzyce - Adam Tomaszewski, 1930-1932, $10 \mathrm{k}$.

18. Witkowo - Adam Tomaszewski, 1930-1932, $10 \mathrm{k}$.

Zestawienie powyższego typu (a nie dotyczy to tylko tego powiatu) poza brakiem możliwości śledzenia zmian historycznych uświadamia także brak podstaw do szkicowania charakterystyki bogactwa słownikowego. Rodzi się zatem konieczność intensyfikowania badań terenowych pozwalających pozyskać materiały umożliwiających podjęcie prac kończących się edycją gwarowego słownika - słownika nawet niewielkiego kompleksu gwar. W odniesieniu do Wielkopolski jest to o tyle istotne, że o podjęcie takich działań upominają się także dialektolodzy z różnych ośrodków Polski:

Ostatnio obserwuje się także natężenie badań nad leksyką polszczyzny dawnych Kresów Wschodnich (14 słowników). Jest szereg regionów, dla których pilnie należałoby sporządzić takie słowniki. Należy do nich Wielkopolska właściwa, Mazowsze właściwe, w tym Kurpie, Podlasie (Karaś 2011, 293) .

5 Podobnie też: (Reichan, Woźniak 2001). 
Wybitny językoznawca polski - prof. Witold Doroszewski - mawiał, że największym problemem dialektologii jest „,brak rąk do pracy”. Zazwyczaj zespoły dialektologów są niewielkie, samodzielne - i pełne - zebranie materiału w terenie często przekracza ich możliwości. Zatem wskazane jest w tej sytuacji odwoływanie się do pomocy środowisk lokalnych. Takie działania od kilku lat podejmowane są w Pracowni Dialektologicznej Instytutu Filologii Polskiej UAM. Najczęściej partnerem lokalnym jest szkoła, z której grupa uczniów angażuje się w akcję pozyskiwania materiałów językowych. W ten sposób można dotrzeć do rozmówców (informatorów) używających (często już tylko pamiętających) poszczególne nazwy lub też praktykujących konkretne zwyczaje. Zaangażowani eksploratorzy (w tym wypadku uczniowie wybranej szkoły) postępują wedle otrzymanych od nas wskazówek. Staramy się zawsze zespół młodych badaczy przygotować merytorycznie - na wstępnych spotkaniach omawiamy sposób i zakres prowadzonych działan. Dostępność aparatów rejestrujących dźwięk pozwala nagrywać całe rozmowy; uczniowie najczęściej wykorzystują do tego telefony komórkowe. Nagrania te są z kolei przekazywane do Pracowni, gdzie podlegają dalszym opracowaniom - transkrypcji (spisywaniu z nagrania) oraz późniejszemu opracowaniu merytorycznemu.

Podejmujący współpracę przedstawiciele środowisk lokalnych poza wskazówkami merytorycznymi otrzymują od nas zestaw pytań (tzw. kwestionariusz) w założeniu mający być podstawą do rozmowy. Ponieważ uczniowie zazwyczaj są już w pewnym stopniu zorientowani w specyfice lokalnego nazewnictwa (a zazwyczaj są to pytania o nazwy konkretnych czynności lub przedmiotów), dostarczony kwestionariusz zawiera pytania o różnej ,skali dokładności”. Przykładowo: w celu pozyskania nazewnictwa związanego z wyrobem masła pytamy najpierw jak się robi masło? W zależności od „otwartości” rozmówcy już na tym etapie możemy uzyskać rejestrację wypowiedzi zawierającej wyrazy, o które w konkretnym kwestionariuszu nie pytaliśmy, daje to też możliwość dokumentacji użycia określeń bardzo rzadkich, często nieznanych dialektologom. Dopiero w dalszej kolejności (kwestionariuszem) staramy się dociec np.: co to jest kierzynka, z jakich części składa się kierzynka, ciecz pozostająca w kierzynce po wyjęciu masła itp. W tej części kwestionariusza wprowadzane są też pytania „o znaczenie" konkretnych wyrazów, np. co to jest podchlebiajek ('wierzchnia cześć konstrukcyjna kierzynki ...’). Zdajemy sobie sprawę, że w wielu miejscowościach wyraz ten nie będzie znany - bo tam takiej nazwy nigdy nie używano, lub też po prostu został już „zapomniany”. Odpowiedzi negatywne (,nie znam”, „u nas tak nie mówili”) dla ogólnej charakterystyki lokalnej gwary mają wartość szczególną, w konfrontacji $\mathrm{z}$ dotychczasową wiedzą (np. porównanie z mapami AJKLW) bowiem mogą także świadczyć o tempie zmian zachodzących w lokalnej gwarze.

Przy okazji staramy się pozyskiwać dokumentację fotograficzną; przy desygnatach szybko wychodzących ze „zbiorowej pamięci” dla wielu późniejszych czytelników (nawet słownika) jest to jedyna możliwość konfrontacji swoich wyobrażeń z „dokumentacją historyczną". W tym miejscu zaznaczę, że z racji zmian językowych zachodzących w środowisku wiejskim zamiast używania terminu gwara preferujemy określenie język mieszkańców wsi (Sierociuk 2007).

Jak wcześniej zaznaczyłem, Wielkopolska - w zestawieniu z innymi dialektami ma najuboższą dokumentacją leksykograficzną. Przedstawione wyżej działania mają na 
celu chociaż częściowe zniwelowanie tej luki. Podjęte zatem w Pracowni Dialektologicznej UAM przedsięwzięcia zaowocowały już ukazaniem się kilku słowników z serii „Wielkopolskie Słowniki Regionalne”, której główna przesłanka odpowiada na kilka założeń. Są to:

- dokumentacja i upowszechnienie gwary niewielkiej okolicy mająca na celu podniesienie na danym terenie świadomości regionalnej; przy takim założeniu słowniki adresowane są do społeczności lokalnej, często takie działanie odbierającej wedle zasady „o nas - dla nas”. Słownictwo określonego zakresu tematycznego poprzedzają informacje o terenie (np. szkic o historii) i współpracującej szkole. Niewątpliwie jest to swoisty rodzaj promocji regionu i jego kultury, zważywszy że każde hasło ilustrowane jest obfitą dokumentacją zawierającą fragmenty autentycznych wypowiedzi informatorów (w miarą możliwości także uzupełnione fotografią desygnatu);

- zróżnicowanie tematyczne słowników wedle ogólnej zasady, że przedkładany zbiór (słownik tematyczny) reprezentuje konkretny zespół dialektalny (np. Wielkopolska wschodnia, Wielkopolska środkowa itp.); daje to możliwość podjęcia próby wyjaśniania złożoności struktury leksykalnej całego kompleksu gwar wielkopolskich. Tematyczne „urozmaicenie” słowników reprezentujących tę samą okolicę realizowane jest z myślą o chociaż częściowej prezentacji bogactwa leksykalnego całości gwar wielkopolskich - w perspektywie mają one być podstawą słownika ogólnowielkopolskiego. Sposób prezentacji materiału wyrazowego uwzględnia jednocześnie możliwość przygotowania dwu wersji słownika - papierowej (aktualnie) i elektronicznej (internetowej) w przyszłości;

- wartość naukowa sprowadza się nie tylko do bogatej dokumentacji; wzgląd na ten aspekt przesądza o umieszczeniu w słowniku także kilku wyrazów luźno powiązanych tematycznie z resztą zbioru. Chodzi o to, żeby były udostępnione informacje istotne z punktu widzenia analiz naukowych - np. historii języka polskiego, lub nawet ważne przy interpretacji niektórych zjawisk (ogólno)slawistycznych. Tym sposobem słownik regionalny znajduje odbiorców daleko poza lokalną społecznością.

W słownikach materiał gwarowy podawany jest - ze względu na odbiorcę lokalnego - w transkrypcji uproszczonej. Przyjmujemy zasadę, że podstawową płaszczyznę stanowi zapis odwołujący się do zasad pisowni ogólnej; na te zjawiska dopiero „nakładamy" osobliwości gwarowe. Nie wprowadzamy też delimitacji tekstu sprowadzającego się do wyodrębniania odcinków syntaktycznych za pomocą przecinków i kropek jako sygnał końca zdania. Staramy się oddać tempo mowy, oznaczając pauzy znakiem ... (wielokropek). W nawiasie umieszczany jest skrót miejscowości, z której pochodzi przywołany cytat lub w której wyraz ten został zarejestrowany. Artykuł hasłowy uzupełniają odesłania do form synonimicznych. Wszystkie formy będące w danym słowniku hasłami podawane są boldem - nawet jeżeli zostały użyte w definicji jakiegoś hasła. Zasadę tę uzupełnia stosowanie kursywy dla zapisu materiału pozyskiwanego $\mathrm{w}$ terenie od informatorów, czcionka normalna zaś stosowana jest w partiach odautorskich - objaśnienie znaczenia lub wtrącenie ułatwiające zrozumienie konkretnego fragmentu wypowiedzi.

Jako przykład przytoczę tu trzy hasła ze słownika ziemi łukowskiej (Sierociuk 2019a): 
harfa - 'tu: pochylnia zrobiona z ułożonych podłużnie szczebelków, zazwyczaj do wrzucania kartofli do piwnicy': do piwnicy kartofle zrzucano ... byty otwory ... takie okna ... i robito sie takie ... żeby to byto doste ${ }^{m} p$ do kartofly ... taki z drewna ... takie szczebelki ... i po tych szczebelkach kartofle leciaty przez te (!) okienko do piwnicy ... taki stojak ... jak coś takiego ... przez to leciało ... do kartofly przerzucania to jes harfa ... (Grz); zob. rafka.

kogutek - 'ustawione w polu snopki': zebrać go ... zwionzać ... zestawić ... w kogutki ... (Żył); kogutki to u nas sie nazywały ... (Żył); zob. dziesiontek, kopa, kopica, kopka 2, kupka 3, mandel, mendelek, myndel.

młynkować - 'oczyszczać zboże młynkiem': najpierw to byty co nie wiała ... tylko tyle co wymtóciła ... i z plewami wszystko szło do wialni ... późni trzeba było mtynkować ... a byty ... późni już byty ... co oddzielały ... wiały ... (Grz); mtynkować ... (Chr); jak sie młóciło wiejko maszyno ... to nie trza było wiać ... a targanko ... i prostomłotno to była wialnia ... trzeba jo byto wialnio ... i późnij młynkować ... na przykład ... trzeba byto ... (̇̇ył).

Według powyższych zasad - w ramach serii „Wielkopolskie Słowniki Regionalne” - aktualnie ukończonych zostało już siedem tomów, przy czym jeden został niedawno złożony w wydawnictwie (zob. niżej wykaz), inne są w fazie opracowania. Przystępność zaproponowanej formy prezentacji materiału gwarowego powoduje, że z wielu środowisk lokalnych mamy sygnały chęci współpracy; wyrażane jest to stwierdzeniem: „my też taki słownik chcemy”.

Mówiąc o dialektologii w Poznaniu, nie sposób pominąć rozwijającej się współpracy z licznymi ośrodkami zagranicznymi. Sprowadza się to przede wszystkim do wymiany założeń teoretycznych i konkretnych osiągnięć w badaniach terenowych; są one prezentowane na konferencjach międzynarodowych. Specyfika dotychczasowych dociekań dialektologii slawistycznej przesądza, że współpraca na tym polu rozwija się głównie między ośrodkami skupionymi w obrębie narodowych akademii nauk. Środowisko poznańskich dialektologów wysoko ceni możliwość bezpośrednich kontaktów wymianę literatury naukowej oraz udział w konferencjach (często współorganizowanych) - z Kolegami z akademickich instytutów Rosji (Petersburg i Moskwa), Ukrainy (Kijów i Lwów), Bułgarii (Sofia), Czech (Brno). Coraz częściej nawiązywane są kontakty naukowe $\mathrm{z}$ przedstawicielami ośrodków dialektologicznych $\mathrm{w}$ innych państwach. Na podkreślenie zasługuje też rozwijająca się wymiana naukowa z zagranicznymi placówkami uniwersyteckimi.

Pracownia Dialektologiczna UAM jest organizatorem - lub też czyni to we współpracy z PTPN oraz innymi zakładami językoznawczymi UAM - dwu cyklicznych konferencji o coraz większym udziale prelegentów zagranicznych. „Gwary dziś” to wcześniej seria wydawnicza PTPN przynosząca od 2001 roku referaty uprzednio wygłaszane na konferencjach z cyklu o takiej samej nazwie; integracja slawistycznego środowiska dialektologicznego pozwoliła przekształcić ją w internetowy rocznik poświęcony dialektologii słowiańskiej, który od 2015 roku - będąc nieformalnym organem Komisji Dialektologicznej przy Międzynarodowym Komitecie Slawistów - jest 
dostępny jako „Gwary Dziś” pod adresem http://gwary.ptpn.poznan.pl/pl/index-pl/ lub https://pressto.amu.edu.pl/index.php/gd. W cyklu dwuletnim natomiast jest (współ)organizowana od 2014 roku konferencja „Język w regionie - region w języku”, której materiały publikowane są pod tym samym tytułem (pierwszy tom ukazał się w Poznaniu w roku 2016).

I na koniec ważne adresy:

http://dialektologia.amu.edu.pl/index.htm

dialektologia@amu.edu.pl

\section{Wielkopolskie Stowniki Regionalne:}

Kobus J., Gniazdowski T. (red.) (2018), Stownik języka mieszkańców okolic Gniezna. Święta, wierzenia i przesądy, Poznań.

Kobus J., Stępień M. (red.) (2018), Stownik języka mieszkańców Czerniejewa. Praca na roli $i w$ gospodarstwie, Poznań.

Kobus J., Migdałek A. (red.) (2021), Słownik języka mieszkańców okolic Pobiedzisk. Praca na roli $i$ w gospodarstwie, Poznań (w druku).

Osowski B. (red.) (2018a), Gospodarz. Słownik języka mieszkańców powiatu kolskiego, Poznań.

Osowski B. (red.) (2018b), Gospodyni. Słownik języka mieszkańców powiatu kolskiego, Poznań.

Osowski B. (red.) (2019), W kuchni u pleszewian. Stownik języka i kultury mieszkańców powiatu pleszewskiego, Poznań.

Sierociuk J. (red.) (2019a), Słownik języka mieszkańców ziemi tukowskiej. Praca na roli i w gospodarstwie, Poznań.

\section{Literatura}

AJKLW - Atlas języka i kultury ludowej Wielkopolski, t. I-VI, pod red. Z. Sobierajskiego i J. Burszty, Wrocław [i in.] 1979-1991, t. VII-XI, pod red. Z. Sobierajskiego, Wrocław [i in.] - Poznań 1992-2005.

Gliszczyńska A. (2007), Germanizmy leksykalne w Atlasie języka i kultury ludowej Wielkopolski, [w:] Gwary dziś. 4. Konteksty dialektologii, pod red. J. Sierociuka, Poznań, s. 275-286.

Gruchmanowa M. (1970), Gwary zachodniej Wielkopolski, Poznań.

Jędraszewski W., Szczepaniak M. (2010), Leksykon miejscowości Wielkiego Księstwa Poznańskiego, z. 1. Powiat Gniezno, Gniezno.

Kaniewska B. (2018), O początku i nie tylko, [w:] Stulecie poznańskiej polonistyki (1919-2019), t. 1. Okres międzywojenny i lata okupacji, pod red. B. Judkowiak, S. Wysłołuch, S. Karolak, A. Piotrowicz, Poznań, s. 11-18.

Karaś H. (2011), Polska leksykografia gwarowa, Warszawa.

Kobus J. (2017), Dokumenty Archiwum UAM dotyczace doc. Adama Tomaszewskiego, „Gwary Dziś” 9, s. 209-213, http://gwary.ptpn.poznan.pl/wp-content/uploads/2019/12/Gwary-9-12Kobus.pdf. 
Kolberg O. (1875-1882), Lud. Jego zwyczaje, sposób życia, mowa, podania, przysłowia, obrzędy, gusła, zabawy, pieśni, muzyka i tańce. Przedstawił Oskar Kolberg. Serya IX. W.Ks. Poznańskie. Część 1-7, Kraków.

Lewaszkiewicz T. (2018), Adam Tomaszewski (1895-1945) - poznański dialektolog, [w:] Stulecie poznańskiej polonistyki (1919-2019), t. 1. Okres międzywojenny i lata okupacji, pod red. B. Judkowiak, S. Wysłołuch, S. Karolak, A. Piotrowicz, Poznań, s. 291-304.

Maciejewski J. (2018), Uniwersyteckie tradycje filologii polskiej w Poznaniu, [w:] Stulecie poznańskiej polonistyki (1919-2019), t. 1. Okres międzywojenny i lata okupacji, pod red. B. Judkowiak, S. Wysłołuch, S. Karolak, A. Piotrowicz, Poznań, s. 21-61.

MAGP - Mały atlas gwar polskich, oprac. Pracownia Dialektologiczna (od t. IV Pracownia Atlasu i Słownika Gwar Polskich) Zakładu Językoznawstwa PAN w Krakowie, t. I-II pod kierunkiem K. Nitscha, t. III-XIII pod kierunkiem M. Karasia, Wrocław-Kraków 1957-1970.

Malepszak S. (2007), Bukowiec Górny. 800 lat dziejów, Bukowiec Górny.

Nowak H. (2001), Od Archiwum Fonograficznego do Zaktadu Dialektologii Polskiej Uniwersytetu im. Adama Mickiewicza w Poznaniu, [w:] Gwary dziś. 1. Metodologia badań, pod red. J. Sierociuka, Poznań, s. 201-212.

Piwowarczyk D.R. (2020), Kazimierz Nitsch - wspóttwórca językoznawstwa polskiego, [w:] My z Nich, 4. Spuścizna językoznawców polskich XX wieku, red. nauk. Z. Greń, K. Kleszczowa, Z. Zaron, Warszawa, s. 129-140.

Reichan J., Woźniak K. (2001), Perspektywy polskiej leksykografii gwarowej, [w:] Gwary dziś. 1. Metodologia badań, pod red. J. Sierociuka, Poznań, s. 33-42.

SGP - Słownik gwar polskich (opracowany przez Zakład Dialektologii Polskiej Instytutu Języka Polskiego PAN w Krakowie), t. I, z. 1. (A-Algiera), Wrocław-Warszawa-Kraków-GdańskŁódź 1979 - t. X, z. 33 (I-Iżyna), Kraków 2019.

SGP 1977, Słownik gwar polskich, opracowany przez Zakład Dialektologii Polskiej Instytutu Języka Polskiego PAN w Krakowie. Źródła, Wrocław-Warszawa-Kraków-Gdańsk.

Sierociuk J. (2003), Założenia metodologiczne badań języka wsi, „Poznańskie Spotkania Językoznawcze”, t. XI, pod red. Z. Krążyńskiej i Z. Zagórskiego, Poznań, s. 131-136.

Sierociuk J. (2005), Z zasobu polskiego słownictwa: Murzyn, [w:] Ad perpetuam rei memoriam. Profesorowi Wojciechowi Ryszardowi Rzepce z okazji 65. urodzin, Poznań, s. 369-374.

Sierociuk J. (2007), Język mieszkańców wsi czy gwara? Problem nie tylko teoretyczny, „Prace Filologiczne", t. LIII, s. 527-534;

Sierociuk J. (2013), W sprawie wielkopolskiej polszczyzny regionalnej, [w:] Cum reverentia, gratia, amicitia ... Ksiega jubileuszowa dedykowana Profesorowi Bogdanowi Walczakowi, pod red. J. Migdał, A. Piotrowskiej-Wojaczyk, t. III, Poznań, s. 205-211.

Sierociuk J. (2018), Henryk Nowak (1932-2010) - cichy dialektolog, [w:] Stulecie poznańskiej polonistyki (1919-2019), t. 2. Językoznawstwo (po roku 1945), pod red. A. Piotrowicz, S. Wysłouch, B. Judkowiak i S. Karolak, Poznań, s. 237-248.

Sierociuk J. (2019b), Gwara - nasz język, nasze dziedzictwo, „Przegląd Wielkopolski”, nr 3 (125), s. 4-12.

Sierociuk J. (2020), Zenon Sobierajski - poznański dialektolog, [w:] My z Nich, 4. Spuścizna językoznawców polskich XX wieku, red. nauk. Z. Greń, K. Kleszczowa. Z. Zaron, Warszawa, s. $185-200$.

Sobierajski Z. (1957), Katalog płytoteki Zakładu Fonograficznego UAM, cz. II, „Biuletyn Fonograficzny" 2, s. 81-109 + mapa. 
Sobierajski Z. (1972), Kwestionariusz do Atlasu języka i kultury ludowej Wielkopolski, cz. I: Stownictwo - Fonetyka - Stowotwórstwo, pyt. 1-645 (współpracowali: M. Gruchmanowa, H. Nowak, Z. Zagórski), cz. II: Deklinacja - Koniugacja - Składnia, pyt. 646-1380 (współpracowali: M. Gruchmanowa, H. Nowak), cz. III: Etnographica, pyt. 1381-1953 (uzupełnienia: T. Wróblewski); cz. IV: Ilustracje, Poznań.

Walczak B. (2018a), Edward Klich (1878-1939) - językoznawca. Życie i twórczość naukowa, [w:] Stulecie poznańskiej polonistyki (1919-2019), t. 1. Okres międzywojenny i lata okupacji, pod red. B. Judkowiak, S. Wysłołuch, S. Karolak, A. Piotrowicz, Poznań, s. 249-260.

Walczak B. (2018b), Wojciech Ryszard Rzepka na tle poznańskiej tradycji językoznawstwa, [w:] Stulecie poznańskiej polonistyki (1919-2019), t. 2. Językoznawstwo (po roku 1945), pod red. A. Piotrowicz, S. Wysłouch, B. Judkowiak, S. Karolak, Poznań, s. 303-314.

Walczak B. (2018c), Zenon Sobierajski (1917-2007) - slawista i dialektolog, znawcza gwar polskich i stowiańskich, [w:] Stulecie poznańskiej polonistyki (1919-2019), t. 2. Językoznawstwo (po roku 1945), pod red. A. Piotrowicz, S. Wysłouch, B. Judkowiak, S. Karolak, Poznań, s. 191-209.

Wikarjak J. (red.) (1972), Uniwersytet Ziem Zachodnich i tajne kursy uniwersyteckie 1939-1945. Pokłosie wspomnień, Poznań.

Zagórski Z. (1967), Gwary pótnocnej Wielkopolski, Poznań.

Zagórski Z. (2011), Językoznawstwo polskie na Uniwersytecie im. Adama Mickiewicza w latach 1919-2009 (w zarysie), Poznań. 